\title{
RANCANG BANGUN HAND SANITIZER OTOMATIS DAN SISTEM MONITORING JARAK JAUH DALAM UPAYA MENGURANGI PENYEBARAN COVID 19
}

\section{DESIGN AND IMPLEMENTATION OF AUTOMATIC HAND SANITIZER AND TELEMONITORING SYSTEM TO REDUCE THE SPREAD OF COVID 19}

\author{
Ari Rahayuningtyas, Novita Dwi Susanti, Eko Kuncoro Pramono, \\ Yusnan Hasani Siregar, Agustami Sitorus, Diang Sagita \\ Pusat Penelitian Teknologi Tepat Guna, Lembaga Ilmu Pengetahuan Indonesia \\ Jalan K.S. Tubun No. 5 Subang, 41211, Jawa Barat, Indonesia \\ e-mail: novitadsanty@gmail.com
}

\begin{abstract}
ABSTRAK
Pada awal tahun 2020, telah terjadi suatu pandemi yang melanda dunia termasuk Indonesia. Pandemi ini disebabkan oleh virus jenis baru yaitu Coronavirus (COVID-19). Upaya untuk mencegah penyebaran virus ini adalah dengan menerapkan protokol kesehatan (memakai masker, menjaga jarak, dan selalu membersihkan tangan). Penelitian ini bertujuan untuk merancang dan mengkonstruksi hand sanitizer otomatis untuk mengurangi penyebaran virus COVID-19. Metode penelitian yang digunakan terdiri dari perancangan fungsional dan struktural, analisis biaya serta uji kinerja. Alat ini dirancang menggunakan beberapa sensor yaitu sensor infra merah (IR Proximity), sensor suhu (MLX90614), dan sensor ultrasonik (HC-SR04). Pengujian karakteristik statik dilakukan pada sensor suhu dan sensor ultrasonik. Analisis karakteristik statik pada sensor dilakukan untuk mengevaluasi kinerja sensor. Hasil menunjukan bahwa nilai deviasi sensor ultrasonik adalah $1,16 \mathrm{~cm}$, deviasi sensor suhu adalah $1,07{ }^{\circ} \mathrm{C}$ dengan tingkat presisi $0,12{ }^{\circ} \mathrm{C}$ serta nilai rata-rata $34,55^{\circ} \mathrm{C}$ pada tiap 5 menit pengukuran. Alat ini mampu mengeluarkan cairan pembersih sekitar 0,2 gram/semprotan. Biaya dasar penyediaan semua komponen perangkat adalah Rp.1,500,000 dan total biaya untuk memproduksi setiap unitnya adalah Rp.2,375,000/unit. Perangkat ini beroperasi tanpa perlu disentuh, dan aman untuk diterapkan di area publik. Perangkat juga dibuat dengan sistem pemantauan terintegrasi dimana suhu tubuh yang diukur oleh perangkat ini dapat dimonitor dari jarak jauh, sehingga memudahkan pengguna dalam pencatatan data.
\end{abstract}

Kata kunci: COVID-19, hand sanitizer, otomatis, sensor

\begin{abstract}
At the beginning of 2020, there is a pandemic that hit the world, including Indonesia. This pandemic is caused by a new type of virus, namely Coronavirus (COVID-19). Efforts to prevent the spread of this virus are to implement health protocols (wear a mask, physical distancing, and always clean our hands). This research aims to design and construct of automatic hand sanitizer to reduce the spread of COVID-19. The methods used were functional and structural design, cost analysis and performance testing. The device was build from several sensors, there is an infrared sensor (IR Proximity), a temperature sensor (MLX90614), and an ultrasonic sensor (HC-SR04). The static characteristic test was carried out on the temperature and ultrasonic sensor. The static characteristics analyses of the sensors were conducted to evaluate the sensor's performance. The results show that the deviation value of the ultrasonic sensor is $1.16 \mathrm{~cm}$, the temperature sensor deviation is $1.07^{\circ} \mathrm{C}$ with a precision of $0.12{ }^{\circ} \mathrm{C}$ and an average value of $34.55^{\circ} \mathrm{C}$ in every 5 minutes of measurement. This device has been able to spray about 0,2 grams of sanitizer/spray. The basic cost for providing all components of the device is Rp.1,500,000 and the total cost for producing each unit of automatic hand sanitizer is Rp.2,375,000/unit. This device operates touchless, and safe to implement in a public area. It also
\end{abstract}


fabricated with an integrated monitoring system, so that the body temperature measured by hand sanitizer can be monitored remotely, making it easier for users to record the data.

Keywords: automatic, COVID 19, hand sanitizer, sensor

\section{PENDAHULUAN}

A wal tahun 2020 telah terjadi pandemi di Indonesia dan berlangsung sampai A saat ini. Pandemi ini terjadi pertama kali di Wuhan China kemudian menyebar ke seluruh dunia. Di Indonesia, virus ini mulai menyebar pada bulan februari 2020 dan jumlah korban semakin banyak setiap harinya. Pandemi ini dikenal dengan Corona Virus Diseases 19 (COVID 19). Untuk menanggulangi virus ini diperlukan pergerakan semua sektor, termasuk sektor penelitian. Sektor penelitian tidak hanya bergerak pada vaksin dan obat melainkan juga pada upaya mengurangi laju penyebaran COVID 19 di Indonesia. Pedoman Pembinaan Perilaku Hidup Bersih Dan Sehat (PHBS) dibidang pencegahan dan penanggulangan penyakit serta penyehatan lingkungan harus dipraktekkan. Salah satunya melalui perilaku mencuci tangan. Mengacu pada protokol yang di canangkan untuk mengurangi penyebaran COVID 19, setiap unit kerja mengimplementasikan protokol di area umum penanganan COVID 19 yaitu dengan mempromosikan cuci tangan secara teratur dan menyeluruh, serta memastikan ketersediaan pembersih tangan (PERMENKES, 2011).

Pada penelitian sebelumnya telah dibahas terkait dengan alat pencuci tangan otomatis diantaranya adalah penelitian Susilo (2015) yang menjelaskan mengenai rancang bangun alat pencuci dan pengering tangan otomatis berbasis mikrokontroler dengan menggunakan sensor passive infrared. Sensor jenis ini memiliki kemampuan rentang jarak yang terbatas antara 1-7 meter masih memiliki respon yang baik namun pada jarak diatas 7 meter sensor tidak merespon. Rizki dan Wildian (2015) telah melakukan rancang bangun sistem wastafel otomatis berbasis mikrokontroler ATmega8535 dengan menggunakan sensor fotodioda. Perancangan sistem sensor digunakan sebuah laser dioda sebagai sumber cahaya dan fotodioda sebagai pendeteksi cahaya. Menurut penelitian Santoso (2008) dijelaskan bahwa alat cuci tangan otomatis ini dirancang dapat menghidupkan pompa air sesuai waktu yang ditentukan, dengan menggunakan sensor optokopler. Tangan pengguna menghalangi sensor optokopler yang menjadi masukan komparator yang mengaktifkan timer sehingga pompa air dapat beroperasi selama 5 detik. Karakteristik statik sensor dicontohkan sesuai penelitian Susanti et al. (2019). Penelitian tersebut menguji kinerja sensor konsentrasi alkohol dengan menghitung nilai presisi, akurasi dan rata-rata penyimpangan sensor.

Berdasarkan beberapa penelitian yang telah dilakukan, alat pencuci tangan otomatis yang dirancang tersebut hanya menggunakan satu jenis sensor, sedangkan pada penelitian ini hand sanitizer otomatis dilengkapi dengan beberapa sensor berupa sensor inframerah tipe Ir Proximity (Silicon Technolabs, 2013) sensor suhu digunakan tipe MLX9016 (Melexis, 2019) dan sensor ultrasonic tipe HC-SR04 (Cytron, 2013) yang bekerja secara terintegrasi dan nilainya dapat ditampilkan pada display LCD. Untuk menguji kehandalan sensor-sensor tersebut perlu dilakukan karakterisasi statik masing-masing sensor. Suhu tubuh pada alat hand sanitizer ini dapat dimonitoring dari jarak jauh sehingga mempermudah pengguna dalam melakukan perekaman data.

\section{BAHAN DAN METODE Bahan dan Alat}

Bahan yang digunakan meliputi bahan mekanik logam untuk konstruksi kotak dispenser hand sanitizer otomatis, bahan elektronik untuk sistem otomatis hand sanitizer otomatis serta pengkodingan dengan menggunakan software Arduino IDE. Peralatan yang digunakan dalam kegiatan ini antara lain: peralatan pendukung perancangan mekanik dan perbengkelan yaitu gerinda tangan, mesin bor tangan, mesin lipat, serta alat pendukung 
lainnya. Bahan mekanik logam dan sistem kontrol diperoleh dari Subang dan sekitarnya. Cairan sanitizer yang digunakan berasal dari cairan alkohol dengan konsentrasi $90 \%$.

\section{Metodologi}

Kegiatan penelitian dibagi menjadi beberapa tahapan yaitu: perancangan fungsional dan struktural, analisis biaya serta uji kinerja perangkat hand sanitizer otomatis.

\section{Perancangan}

Pada penelitian ini menggunakan konsep rancang bangun yang terdiri dari beberapa tahapan antara lain perancangan, konstruksi dan pengujian. Asumsi yang diambil dalam rancang bangun ini adalah berdasar anjuran untuk menerapkan protokol kesehatan untuk mencuci tangan disetiap lingkungan kerja dan tempat umum, sehingga untuk menghindari kontak langsung dengan alat hand sanitizer maka diperlukan sistem yang otomatis dengan memasang sensor inframerah yang akan menggerakkan pompa untuk mengeluarkan cairan hand sanitizer dan pengecekan suhu tubuh pegawai setiap hari. Hand sanitizer otomatis ini diletakkan di pintu masuk gedung dan tempat umum.

\section{Perancangan Fungsional}

Bagian-bagian hand sanitizer otomatis ini adalah: wadah cairan alkohol, kotak rangkaian elektronik, sensor inframerah untuk menggerakkan pompa peristaltik sehingga dapat mengeluarkan cairan alkohol dari wadah, sensor suhu untuk mendeteksi suhu tubuh yang nilainya dapat ditampilkan pada display $L C D$.

\section{Perancangan Struktural}

Dimensi hand sanitizer otomatis mempunyai ukuran $100 \mathrm{~cm} \times 15 \mathrm{~cm}$ rangka tersusun dari aluminium berukuran $2 \mathrm{~cm} \times 4 \mathrm{~cm}$, kotak elektronik berukuran $18,5 \times 15 \mathrm{~cm}$ terbuat dari bahan aluminium berukuran $2 \mathrm{~cm} \times 4 \mathrm{~cm}$, dilengkapi dengan sensor inframerah tipe $I R$ Proximity, sensor suhu tipe MLX9016, sensor ultrasonik tipe HC-SR04 dan monitoring sistem berbasis internet.

\section{Perhitungan Analisis Biaya}

Biaya pokok produksi adalah total biaya yang dibutuhkan untuk menghasilkan setiap unit produk. Biaya pokok produksi alat ini dihitung menggunakan metode yang dipakai oleh Rahayuningtyas et al., (2020: 70). Total biaya produksi diperoleh dari penjumlahan biaya tetap ( fixed cost) dan biaya variabel (variable cost). Komponen yang termasuk biaya tetap dalam perancangan ini adalah biaya penyusutan (depreciation) alat yang dihitung dengan menggunakan metode straight line tanpa memperhitungkan bunga modal. Biaya penyusutan dihitung menggunakan Persamaan 1.

$$
D=\frac{(P-S)}{L}
$$

Dimana:

$$
\begin{array}{ll}
D & : \text { biaya penyusutan tiap tahun (Rp/hari) } \\
P & : \text { harga awal (Rp) } \\
S & : \text { harga akhir (Rp) } \\
L & : \text { perkiraan umur ekonomis (hari) }
\end{array}
$$

Biaya tidak tetap terdiri dari biaya bahan baku, tenaga kerja, listrik, biaya perbaikan atau pemeliharaan, dan biaya operasional atau transportasi.Biaya pokok pembuatan hand sanitizer otomatis dihitung menggunakan Persamaan 2. 


$$
B P P=\frac{B T}{(K \times X)}+\frac{B T T}{K}
$$

Dimana:

$$
\begin{array}{ll}
B P P^{\prime} & \text { : biaya pokok produksi (Rp/unit produk) } \\
B T & \text { : biaya tetap (Rp/tahun) } \\
B T T & \text { : biaya tidak tetap (Rp/hari) } \\
K & : \text { kapasitas alat (unit produk/hari) } \\
X & \text { : perkiraan hari kerja dalam satu tahun (hari/tahun) }
\end{array}
$$

\section{Uji Karakteristik Statik Sensor}

Karakteristik statis suatu alat ukur adalah karakteristik yang harus diperhatikan apabila alat tersebut digunakan untuk mengukur suatu kondisi yang tidak berubah karena waktu atau hanya berubah secara lambat laun. Karakteristik statis terdiri atas, kalibrasi, ketelitian atau akurasi, ketepatan atau presisi, kepekaan, jangkauan dan kesalahan pengukuran (Nugraha and Ramadhan, 2018). Pada penelitian ini uji karakteristik dilakukan terhadap sensor suhu, dan ultrasonik. Uji yang dilakukan meliputi kalibrasi dan akurasi sensor ultrasonik. Selain itu dengan kalibrasi, akurasi, presisi dan repeatability pembacaan sensor suhu. Nilai akurasi sensor merupakan nilai penyimpanagn (deviasi) pembacaan sensor terhadap nilai sebenarnya diperoleh dari Persamaan 3.

$$
\sigma=\sqrt{v}=\frac{\sqrt{d 1^{2}+d 2^{2}+\cdots d n^{2}}}{\mathrm{n}-1}
$$

Dimana:

$$
\begin{array}{ll}
\sigma & : \text { deviasi } \\
V & : \text { varian } \\
d & : \text { selisih antara pembacaan sensor dengan nilai rata-rata } \\
\underline{n} & : \text { jumlah sampel }
\end{array}
$$

\section{HASIL DAN PEMBAHASAN}

\section{Perancangan Sistem Mekanik Hand Sanitizer Otomatis}

Pendekatan perancangan yang dilakukan adalah merancang sistem elektronik dan mekanisme pompa untuk mengeluarkan alkohol berdasarkan sensor yang mendeteksi tangan saat berada di area penyemprotan. Cairan alkohol yang digunakan memiliki konsentrasi $90 \%$ dalam wadah 1 liter. Dimensi hand sanitizer otomatis berukuran $100 \mathrm{~cm} \times 15 \mathrm{~cm}$. Rangka tersusun dari batang aluminium ukuran $2 \mathrm{~cm} \times 4 \mathrm{~cm}$, kotak elektronik berukuran $18,5 \mathrm{~cm} \times$ $15 \mathrm{~cm}$ terbuat dari batang aluminium ukuran $2 \mathrm{~cm} \times 4 \mathrm{~cm}$. Desain dari perangkat hand sanitizer otomatisdisajikan pada Gambar 1 dan Prototipe alat disajikan pada Gambar 2.

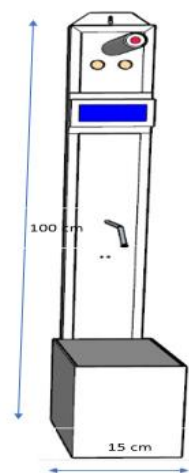

Gambar 1. Desain dari perangkat hand sanitizer otomatis 


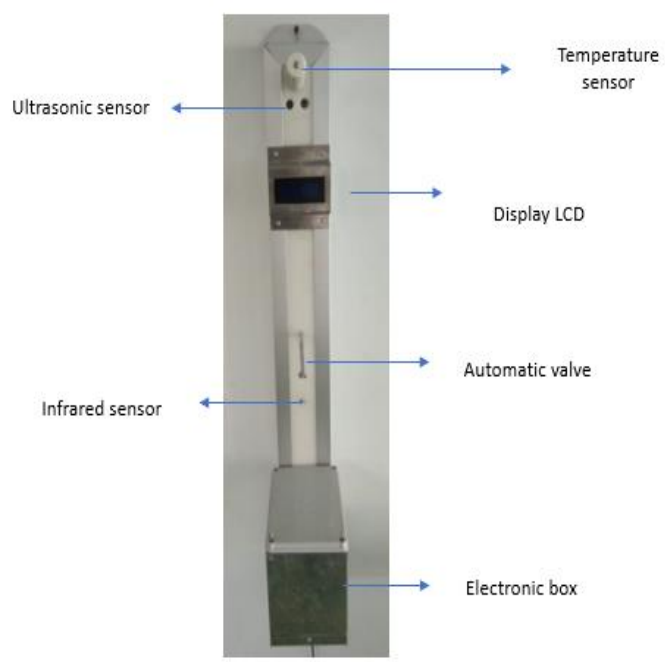

Gambar 2. Hand sanitizer otomatis tampak keseluruhan

\section{Perancangan Sistem Elektrik}

Sensor suhu, sensor ultrasonic dan sensor inframerah merupakan faktor terpenting pada alat ini. Selain itu beberapa rangkaian elektronik juga mendukung keberhasilan alat ini. Pada handsanitier otomatis ini diperlukan sensor inframerah tipe Ir Proximity (Silicon Technolabs, 2013) untuk menggerakkan pompa peristaltik sehingga dapat mengeluarkan cairan alkohol dari wadah, sensor suhu digunakan tipe MLX9016 (Melexis, 2019) untuk mendeteksi suhu tubuh dan sensor ultrasonic tipe HC-SR04 (Cytron, 2013) yang nilainya dapat ditampilkan pada display $\angle C D$ dan suhu tubuh diproses oleh mikrokontroler sebagai pemroses data kemudian data diolah lebih lanjut sehingga dapat ditampilkan dan diakses lewat internet. Diagram blok sistem perancangan elektronik dapat dilihat pada Gambar 3.

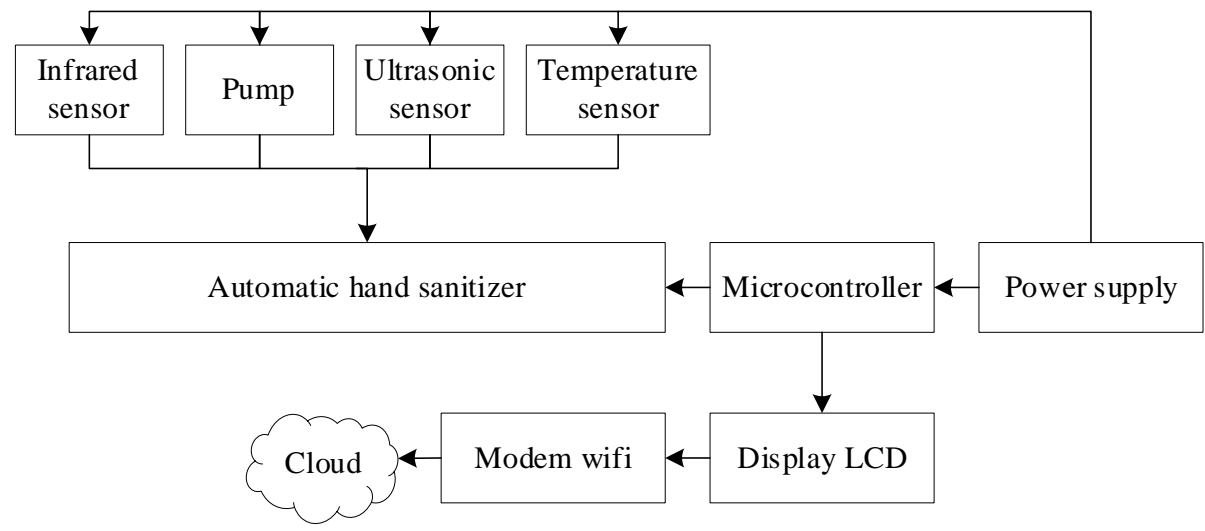

Gambar 3. Diagram blok sistem perancangan elektronik hand sanitizer otomatis

\section{Prinsip Kerja Hand Sanitizer Otomatis}

Alur proses kerja sistem hand sanitizer otomatis dimulai ketika tangan didekatkan pada sensor inframerah berjarak sekitar $5 \mathrm{~cm}$ dan sensor aktif (posisi on) kemudian akan menggerakkan pompa perilstatik sehingga dapat mengeluarkan cairan alkohol dari wadahnya (Gambar 4). Satu kali penyemprotan memerlukan waktu 1 detik dengan berat $\pm 0,2$ gram. 


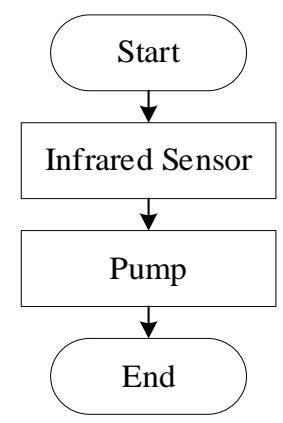

Gambar 4. Diagram alir pengeluaran cairan

Pengukuran suhu tubuh dilakukan disekitar kening berjarak sekitar $2 \mathrm{~cm}$ dengan menggunakan sensor ultrasonik. Ketika suhu terdeteksi $>37.5^{\circ} \mathrm{C}$ maka akan terdengar bunyi pada buzzer yang menandakan bahwa seseorang tersebut pada kondisi badan dengan suhu melebihi panas normal (Gambar 5). Nilai suhu tubuh ditampilkan pada layar $L C D$.

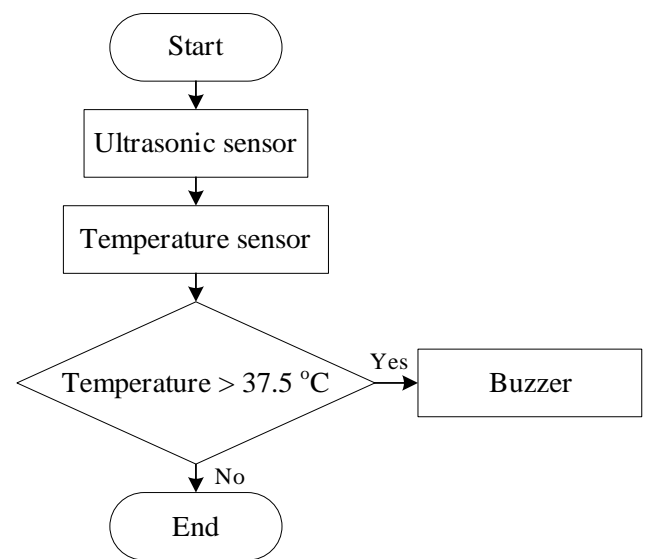

Gambar 5. Diagram alir pengukuran suhu tubuh

\section{Kinerja Sensor Ultrasonik}

Pengukuran kinerja sensor ultrasonik yang dilakukan adalah akurasi sensor. Tujuannya adalah untuk membandingkan kemampuan ukur sensor ultrasonik dengan alat ukur standar (dalam hal ini menggunakan penggaris). Pengumpulan data sebanyak 50 sampel. Dari hasil pembacaan tersebut diperoleh grafik sesuai Gambar 6.

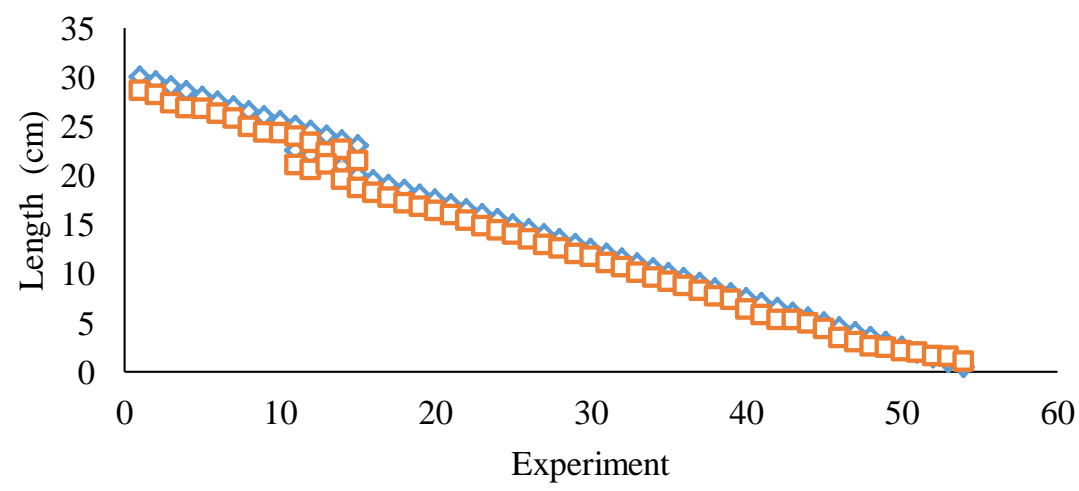

$\diamond$ ultrasonic sensor $\quad-\square-$ Standart measurement

Gambar 6. Perbandingan pembacaan sensor jarak dengan alat ukur terstandar 
Dari Gambar 6 terlihat bahwa pembacaan sensor memiliki perbedaan nilai pembacaan jika dibandingkan dengan alat ukur standar sehingga diperlukan koreksi terhadap perbedaan pembacaan nilai tersebut. Tujuan kalibrasi adalah untuk memastikan pembacaan suatu instrumen konsisten dengan instrumen pengukuran lainnya (Bentley, 2005). Gambar 7 menunjukkan hasil korelasi pembacaan sensor ultrasonik dengan alat ukur standar.

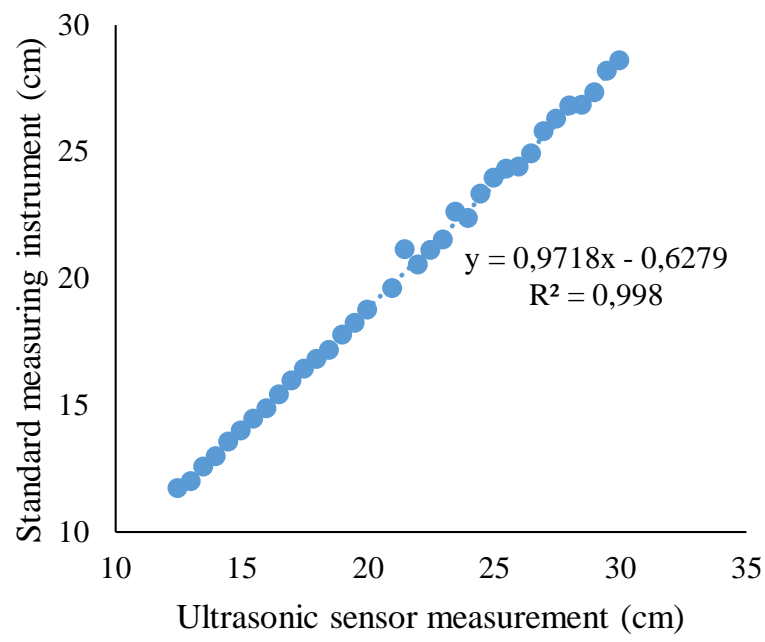

Gambar 7. Perbandingan jarak yang diukur dengan sensor ultrasonik dan alat ukur standar

Dari Gambar 7 dapat dijelaskan bahwa terdapat perbedaan hasil pembacaan pengukuran antara sensor dan alat ukur standar, selisih tersebut kemudian dibandingkan untuk mendapatkan persamaan koreksi kalibrasi. Dari hasil perhitungan diperoleh root mean square error (RMSE) dari pengukuran sensor ultrasonik adalah 1,357 dan deviasi rata-rata $1,16 \mathrm{~cm}$. Berdasarkan hasil perhitungan, persamaan koreksi $0.9718 x-0.6279$ dapat digunakan untuk mengkalibrasi pengukuran sensor ultrasonik dengan nilai $\mathrm{R}^{2}$ yang tinggi (0.998).

\section{Kinerja Sensor Suhu}

Pengujian ini meliputi kalibrasi, akurasi, presisi dan repeatability pembacaan sensor suhu. Adapun hal yang dilakukan meliputi melakukan kalibrasi sensor suhu, yaitu membandingkan kemampuan jarak sensor suhu dengan alat ukur standart dalam hal ini adalah thermometer Infrared FLUKE 59 Max. Pengambilan data sebanyak 10 sampel. Dari pembacaan dapat diperoleh grafik sesuai Gambar 8.

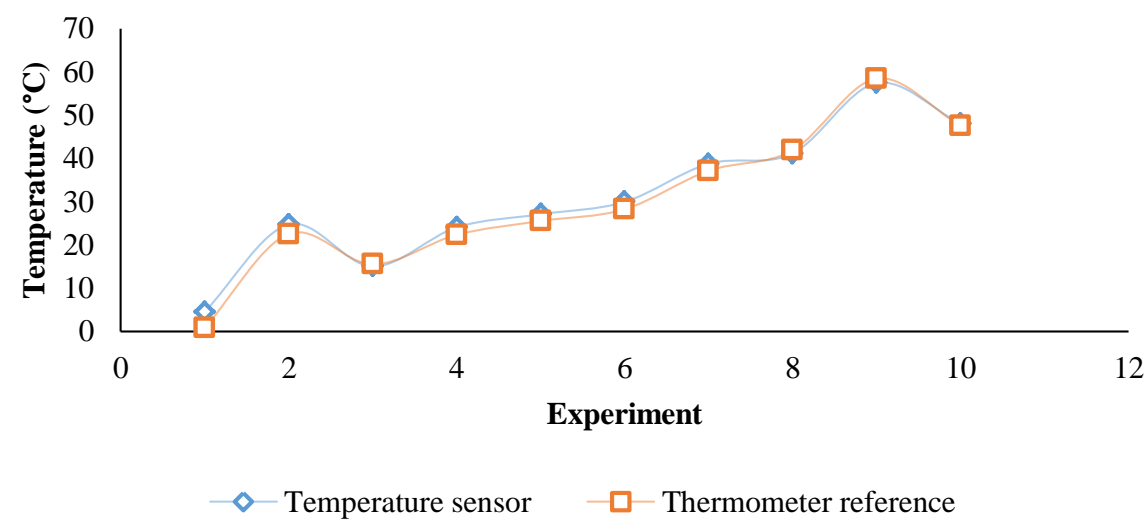

Gambar 8. Perbandingan pembacaan sensor suhu dengan alat ukur terstandar 
Berdasarkan Gambar 8 terdapat perbedaan nilai pengukuran oleh sensor jika dibandingkan dengan alat ukur standar sehingga perlu adanya koreksi terhadap perbedaan pembacaan nilai tersebut. Ini karena sensor suhu dipengaruhi oleh berbagai kondisi lingkungan termasuk proses manufaktur dan perakitan akhir perangkat. Faktor-faktor tersebut dapat mempengaruhi akurasi pembacaan sensor. Gambar 9 menunjukkan hasil korelasi percobaan pembacaan sensor suhu dengan termometer referensi.

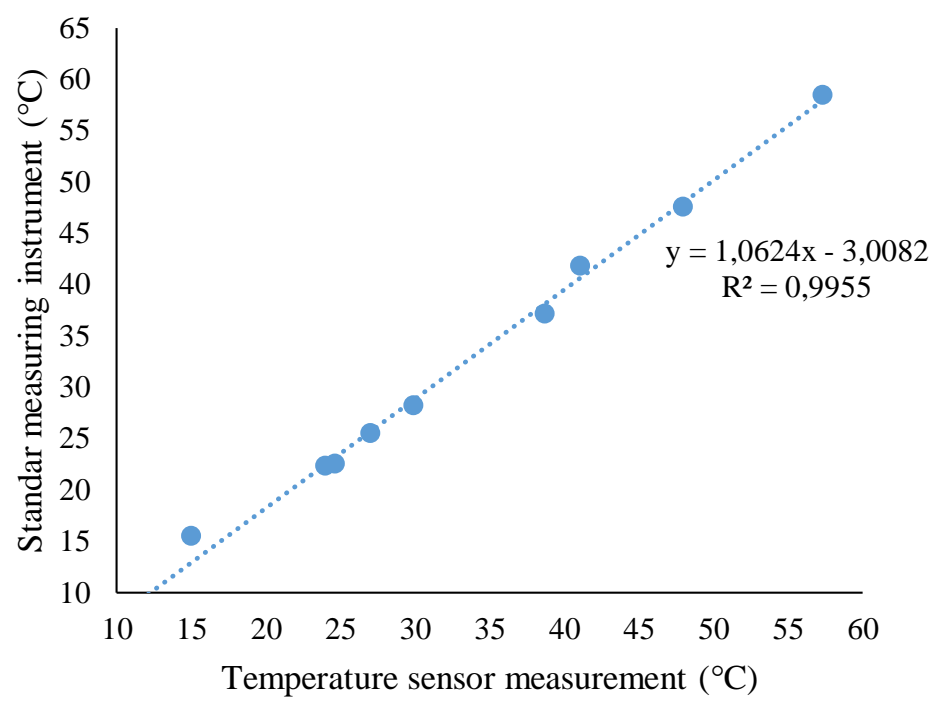

Gambar 9. Hasil pengukuran suhu dengan sensor dan instrumen standar

Gambar 9 menunjukkan bahwa terdapat perbedaan antara pembacaan sensor suhu dan pembacaan alat ukur, penyimpangan ini kemudian dijumlahkan untuk menentukan penyimpangan total yang dapat menentukan keakuratan sensor suhu. Berdasarkan data, deviasi rata-rata adalah $1.07{ }^{\circ} \mathrm{C}$. Dalam hal penentuan presisi dan pengulangan, Tabel 1 menunjukkan hasil percobaan pengukuran 10 ulangan.

Tabel 1.Percobaan pembacaan sensor suhu untuk mengetahui nilai presisi sensor suhu

\begin{tabular}{cc}
\hline Percobaan & Suhu $\left({ }^{\circ} \mathrm{C}\right)$ \\
\hline 1 & 34.03 \\
2 & 34.09 \\
3 & 34.21 \\
4 & 34.09 \\
5 & 34.31 \\
6 & 34.05 \\
7 & 34.41 \\
8 & 34.03 \\
9 & 34.27 \\
10 & 34.11 \\
\hline Rata-rata & 34.16 \\
\hline Standar deviasi & 0.12
\end{tabular}

Tingkat presisi suatu alat ukur adalah kemampuan alat tersebut untuk mengukur secara benar dan andal dengan membandingkan hasil pembacaan sensor dengan nilai ratarata hasil pembacaan sensor (Morris, 2001). Berdasarkan Tabel 1 dan persamaan (3) diperoleh nilai presisi $0,12^{\circ} \mathrm{C}$. Tabel 2 menunjukkan hasil percobaan pengukuran suhu pada 
5 ulangan untuk mengetahui pengulangan atau kemampuan sensor suhu membaca kembali dalam kurun waktu tertentu. Dari Tabel 2 didapatkan nilai rata-rata hasil pembacaan sensor dengan 5 kali pengulangan setiap 5 menit adalah $34.55^{\circ} \mathrm{C}$.

Tabel 2. Percobaan pembacaan sensor suhu untuk menentukan repeatability sensor suhu

\begin{tabular}{cc}
\hline Waktu & Suhu $\left({ }^{\circ} \mathrm{C}\right)$ \\
\hline 9.30 & 34.59 \\
9.35 & 34.55 \\
9.40 & 34.90 \\
9.45 & 34.59 \\
9.50 & 34.11 \\
\hline
\end{tabular}

\section{Analisa Biaya}

Analisis biaya digunakan untuk menentukan total biaya yang harus dikeluarkan saat membuat perangkat hand sanitizer ini. Tabel 3 menunjukkan nilai penyusutan peralatan bengkel mekanik yang digunakan untuk pembuatan hand sanitizer otomatis berdasarkan Persamaan 1.

Tabel 3. Biaya depresiasi peralatan mesin*

\begin{tabular}{clrcr}
\hline No & \multicolumn{1}{c}{ Nama alat } & Harga (Rp.) & $\begin{array}{c}\text { Umur alat } \\
\text { (tahun) }\end{array}$ & $\begin{array}{r}\text { Depresiasi } \\
\text { (Rp/hari) }\end{array}$ \\
\hline 1 & Gerinda tangan 4' & Rp.1,250,000 & 2 & Rp.1,541 \\
4 & Mesin bor tangan & Rp.1,000,000 & 2 & Rp.1,233 \\
5 & Mesin lipat & Rp.10,000,000 & 10 & Rp.2,466 \\
7 & Alat kikir & Rp.200,000 & 1 & Rp.493 \\
8 & Palu & Rp.200,000 & 1 & Rp.493 \\
\hline & Total depresiasi, Rp/hari & & & Rp.6,226 \\
\hline
\end{tabular}

*berdasar perhitungan

Proses pembuatan perangkat hand sanitizer otomatis ini menghabiskan waktu 2 hari sehingga besarnya biaya penyusutan adalah Rp. 6,226 per hari. Biaya tidak tetap dapat dilihat pada Tabel 4 yang terdiri dari biaya bahan baku, biaya tenaga kerja, biaya listrik, dan biaya operasional.

Tabel 4.Biaya Tidak Tetap Pembuatan Alat*

\begin{tabular}{|c|c|}
\hline Jenis biaya & Biaya(Rp/unit) \\
\hline Biaya bahan baku alat & Rp. $1,500,000$ \\
\hline Biaya tenaga kerja & Rp.675,000 \\
\hline Biaya listrik & Rp. 100,000 \\
\hline Biaya pemeliharaan & Rp. 50,000 \\
\hline Biaya operasional & Rp. 50,000 \\
\hline Total biaya tidak tetap(Rp/unit) & Rp. $2,375,000$ \\
\hline
\end{tabular}

Pembuatan hand sanitizer ini membutuhkan biaya bahan baku hingga Rp.1,500,000. Biaya pembuatan didasarkan pada jumlah pekerja sebanyak 3 orang dengan hari kerja 7 jam / hari, dan biaya tenaga kerja sebesar Rp.75,000 / tenaga kerja per hari. Berdasarkan biaya yang disebutkan pada Tabel 4 dan 5 serta menggunakan Persamaan 2 maka total biaya produksi (BPP) yang dibutuhkan adalah Rp.2,375,000 per unit. 
Dalam hal pemanfaatan hand sanitizer otomatis ini, biaya implementasi alat ini dapat dilihat pada Tabel 5. Penyusutan alat dihitung menggunakan Persamaan 1. Asumsi masa manfaat adalah 3 tahun dan hari kerja perangkat adalah 365 hari / tahun. Satu siklus penyemprotan membutuhkan waktu 1 detik dan debit 0,2 gram sanitizer. Satu botol cairan sanitizer mengandung sanitizer dengan konsentrasi alkohol 90\%. Dalam hal ini 1 botol berisi cairan sanitizer sebanyak 836,6 gram, sehingga diperkirakan satu botol cairan sanitizer dapat digunakan sebanyak 4183 kali dengan harga 1 liter cairan sanitizer Rp.50,000. Jika diasumsikan penggunaan alat tersebut 500 semprotan per hari, berarti dalam waktu 8 hari sanitizer akan habis sehingga biaya per hari Rp. 6,250 per hari. Tenaga kerja sangat penting, terutama untuk mengisi kembali cairan sanitizer bila habis dan untuk perawatan alat, sehingga biaya tenaga kerja sebesar Rp.75,000 per 8 hari (Rp. 9,375 / hari). Konsumsi listrik alat ini sekitar 50 watt dan dioperasikan secara full time sehingga biaya listrik sebesar Rp.1,800 per hari (listrik komersial Rp.1,500 per kWh). Pemeliharaan diasumsikan $10 \%$ dari harga per tahun. Total biaya yang dibutuhkan per hari untuk penggunaan perangkat ini adalah Rp.20,346.

Tabel 5. Biaya implementasi hand sanitizer otomatis*

\begin{tabular}{lr}
\hline Jenis biaya & Biaya (Rp/hari) \\
\hline Biaya tetap: & \\
Depresiasi alat & $\mathrm{Rp} .2,168$ \\
\hline Biaya tidak tetap: & \\
- Konsumsi cairan sanitizer & $\mathrm{Rp} .6,250$ \\
- Tenaga kerja & $\mathrm{Rp} .9,375$ \\
- Listrik & $\mathrm{Rp} .1,800$ \\
- Pemeliharaan alat & $\mathrm{Rp} .753$ \\
\hline Total biaya, Rp/hari & $\mathrm{Rp} .20,346$ \\
\hline *berdasar peritungan &
\end{tabular}

\section{KESIMPULAN}

Perangkat hand sanitizer otomatis telah dirancang dan dikonstruksi dengan ukuran $1000 \mathrm{~mm} \times 150 \mathrm{~mm}$. Alat ini dilengkapi dengan sensor infra merah (IR Proximity), sensor suhu tipe MLX90614 dan sensor ultrasonik tipe HC-SR04. Alat ini mampu mengeluarkan cairan pembersih sekitar 0,2 gram/semprotan. Konsentrasi sanitizer adalah $90 \%$ gram alkohol / mililiter, sehingga 1 botol berisi cairan sebanyak 836,6 gram. Diperkirakan 1 botol cairan sanitizer dapat digunakan sebanyak 4183 kali. Pada penelitian ini dilakukan uji karakteristik statik pada sensor suhu dan ultrasonik. Pengujian karakteristik sensor ultrasonik mengambil 50 sampel berdasarkan perhitungan yang memiliki nilai deviasi $1,16 \mathrm{~cm}$. Untuk pengujian karakteristik sensor suhu diperoleh nilai deviasi $1,07^{\circ} \mathrm{C}$, kepresisian $0,12{ }^{\circ} \mathrm{C}$, dan hasil pengukuran pengulangan setiap 5 menit adalah $34,55^{\circ} \mathrm{C}$. Besarnya biaya dasar penyediaan semua komponen alat adalah Rp.1,500,000 dan total biaya untuk memproduksi setiap unit alat tersebut adalah Rp.2,375,000 per unit. Suhu tubuh yang diukur dengan hand sanitizer dapat dipantau dari jarak jauh sehingga memudahkan dalam proses perekaman data.

\section{UCAPAN TERIMA KASIH}

Penulis mengucapkan terimakasih kepada Pusat Penelitian Teknologi Tepat Guna Lembaga IImuPengetahuan Indonesia dan pihak-pihak yang terlibat penelitian ini. 


\section{DAFTAR PUSTAKA}

Bentley, P. 2005. Principles of Measurement Systems, Fourth. Prentice Hall, New Jersey.

Cytron. 2013. Product User's Manual - HCSR04 Ultrasonic Sensor. https://www.electroschematics.com/hc-sr04-datasheet/. 15 September 2020.

Melexis. 2019. Digital Non-Contact Infrared Thermometer (MLX90614) \#Melexis. https://www.melexis.com/en/product/mlx90614/digital-plug-play-infraredthermometer-to-can. 15 September 2020.

Morris, A. 2001. Measurement and Instrumentation Principle. Butterworth Heinemann, Boston.

Nugraha, A., dan M. N. Ramadhan. 2018. Pengukuran Teknik dan Instrumentasi. Universitas Lambung Mangkurat, Banjarmasin.

Peraturan Menteri Kesehatan RepublikIndonesia (PERMENKES) No: 2269/MENKES/PER/XI/2011 Pedoman pembinaan perilaku hidup bersih dan sehat(PHBS). November 2011. Jakarta: Kementerian Kesehatan Republik Indonesia.

Rahayuningtyas, A., M. Furqon, dan D. Sagita. 2020. Rancang bangun perangkat sortasi tomat berdasar sensor berat tipe strain gauge dan pengolahan citra warna design of tomato sortation device based on strain gauge type weight sensor and color image processing. Jurnal Riset Teknologi Industri 14 (1): 65-78.

Rizki, H., dan Wildian. 2015. Rancang Bangun Sistem Wastafel Otomatis Berbasis Mikrokontroler Atmega8535 Dengan Menggunakan Sensor Fotodioda. Jurnal Fisika Unand 4 (2): 106-112.

Santoso, H. 2008. Mesin Pencuci Tangan Otomatis Menggunakan Sensor Optokopler. Skripsi. Program Studi Teknik Elektro. Fakultas Sains Dan Teknologi. Universitas Sanata Dharma. Yogyakarta.

Silicon Technolabs. 2013. IR Proximity Sensor Datasheet. https://components101.com/sites/default/files/component_datasheet/Datasheet of IR Sensor.pdf. 15 September 2020.

Susanti, N. D., P. H. Rusmin, A. S. Rohman, and E. J. Pristianto. 2019. Design of Ethanol Concentration Measurement System Using Specific Gravity Approach for Batch Distillation Column Automation dalam International Conference on Radar, Antenna, Microwave, Electronics, and Telecommunications Design (ICRAMET) Tangerang Indonesia. Oktober 23-24. 148-151.

Susilo, D. 2015. Rancang Bangun dan Implementasi system pencuci tangan (Hand Washer) dan pengering tangan (Hand Dryer) otomatis berbasis mikrokontroller atmega 8535. Skripsi. Fakultas Teknik. Universitas Brawijaya. Malang. 